\title{
The Hand with the Pen: Martin of Loka, Matjaž Jurčič of Kapela and Herman Talner of Trebnje and their Colophons*
}

Keywords: Mediaeval manuscripts, author's autograph, copyist's autograph, ideograph, prosopography, Martin of (Škofja) Loka, Matjaž Jurčič of Kapela, Herman Talner of Trebnje

DOI: 10.4312 /ars.8.2.87-118

\section{Memory and Oblivion}

Although some scientific postulates do not last for an eternity, they can nevertheless be long-lived, deeply entrenched and reside as a semi-transparent ghost in the general perception of a scientific field or phenomenon. In such a way we have - with an unreasonable lack of objectivity - adopted the phrase the anonymous Middle Ages.' The reasons for this elude detection, yet it seems to be a point of view stemming from a time in the tradition of the modern humanities when the perception of artistic and philosophical currents leaped from the idealizations and fanciful deliberations on the greatness of Antiquity straight to the illuminated realm of the Renaissance; meanwhile, an entire millennium in between remained in the basement of the 'Dark Middle Ages.' Even today, this remains true in many places and in the minds of many people. After all, several influential publications implicitly perpetuated this opinion. One can take, for example, the 'bestseller' by Jacob Burckhardt The Civilization of the Renaissance in Italy, first published in $1860,{ }^{1}$ an important work for the history of culture and art that was published on the threshold of Art History, which was entering the universities at the time as a humanist study in its own right. However, Burckhardt also wrote several statements which attribute the wrong qualities to the Middle and New Ages. With the sharpness of chiaroscuro, he chiselled out the contrast between the anonymity of the mediaeval author and the Renaissance advent of individuality, between the authorial ambiguity of mediaeval works, and Renaissance creations bearing the artist's signature. He thereby created an unfounded antagonism. Despite the

* The Slovene version of this article is available on: http://revije.ff.uni-lj.si/arshumanitas. / Slovenska različica članka je dosegljiva na: http://revije.ff.uni-lj.si/arshumanitas.

1 The Slovene translation was published nearly 100 years later, in 1956. 
respect and recognition Jacob Burckhardt deserves, these opinions can no longer be considered as the 'gold standard.'

Nearly at the same time, around the mid- $19^{\text {th }}$ century - with a small amount of thanks owed to Romanticism - in France and Germany, the Middle Ages began to be recognized as the period in which their modernity began; on the Iberian peninsula and in Great Britain the recognition of the importance of mediaeval events never really faded. There was a common understanding in Europe that modern European countries and their citizens grew out of the Middle Ages and that, over the course of the following centuries, they had been formed through their own events, political personae, creators and creations, into their modern selves - that history was a waveform of change. Investigations and research started in most European countries and they delved right into the heart of those temporarily lost memories: their findings heavily influenced the self-confidence and political posture of both individuals and states. It is therefore rather incredible that even as late as 1966 Francè Stelè had to add the following to his Introduction on the publishing of the re-print of his "Outline of Art History among Slovenians" (Oris zgodovine umetnosti pri Slovencih, Stelè 1966, p. 21):

If we who call ourselves Slovenians therefore speak of the relation art has to this group of people, there is not, and can never be, a question of whether we have now and if we had ever had our own art in the past, but only the question of how we perceived this art, and how our distinct character broadcasted itself as an individual example of the multi-faceted river of Life. The phrase that we, the Slovenes, do not have our own art has to be refuted ad acta, just as we have done with a similar phrase, the one saying we do not have a history. ${ }^{3}$

Stelè could have perhaps also added a word on the indisputable intellectual presence in our Middle Ages, as these creations, these works of art he had spent his entire life writing about, after all, rose out of a mental substrate. He and Milko Kos

2 Cf. Klotz, 303, who lists examples from the $6^{\text {th }}$ century onward. - It is even more unusual to read the statement by Charlotte Guichard, published in a 2012 article, that the artist's name had appeared within the field of painting or sculpture (and not on the frame or pedestal) only with the advent of the Renaissance. Nicolas of Verdun had proudly signed himself in 1181 right in the centre of his goldsmith work, and he was merely one of hundreds of similarly disposed artists of the times. Cf. Guichard, p. 47.

3 The question of denigrating the historic and artistic heritage of Slovenes belongs to a discussion with an explicitly political framework. We should still try not to forget that he had written this only shortly before the ground-breaking exhibition of Yugoslavian art in Paris, which had presented Yugoslavia (then a respected member of the international community) and the art in its territory from prehistoric times up to 1970. It was Francè Stelè himself who was the central arbiter of this important cultural event as its editor and secretary of the organisation. In that same year, the exhibition was transported from the Grand Palais to Sarajevo under the title Umjetnost na tlu Jugoslavije od praistorije do danas, Sarajevo 1971. 
had also collaborated on a catalogue of mediaeval manuscripts preserved in Slovene collections: ${ }^{4}$ the manuscripts and the index of names contain many identities of those who had copied, decorated and bound these manuscripts. There may be names aplenty, yet they are almost never accompanied by information on where they had come from, where and when these persons had laboured, where they had studied, or what their other activities were, though tiny details from their everyday life are fairly common. But above all, we have their works, and these speak in their place.

\section{Autographs and Colophons}

The person and personality of a mediaeval artist represents an area of work entailing a multitude of tiny pieces of information that need to be put together. When we are discussing manuscript workers, the most informative fields are the colophons and other captions added to various manuscripts, though the existence of a broad, eloquent self-presentation is still a rarity. ${ }^{5}$ These manuscript workers were not often noted in literary and other historical sources, and this has much to do with their mobility. ${ }^{6}$ The craftsmen were not clerics to be stationed in a single location; they would not have had their names and deeds written down in the chronicles of the local church or monastery, and they would have moved often, wherever work took them (Hamon, 62). The time of artists hailing primarily from the ranks of the Church had passed ca. 1200 A.D.: if by the mid- $12^{\text {th }}$ century nearly all of the manuscripts were made by the knowledgeable monks in monasteries, after 1250 approximately $70 \%$ of the manuscripts were made in lay scriptoria, ${ }^{7}$ that is, in municipal manuscript workshops.

4 Kos - Stelè, p. 231 onward; Index personarum locorum rerum, which is a truly praiseworthy instrument of assistance.

5 The colophons in Glagolitic manuscripts certainly stand out, particularly in those from the $14^{\text {th }}$ and $15^{\text {th }}$ centuries from northern Dalmatia and Lika, written in an epic diction of themselves, their family, local and distant events. Cf. Golob, 1993, p. 450-461, especially 457 ss.

6 The topic of itinerant artisans in the Middle Ages has become an extensive field of research in the history of art, history and sociology; see. P. Kurmann on the question of itinerant artisans and migrating patterns; for our area, the contribution by G. Schmidt on the travels of illuminators in the $14^{\text {th }}$ century is of particular interest.

7 After 1250 the copying (and decorating) of manuscripts remained in those monasteries, which lived an isolated life according to their monastic principles, and had nearly no contact with the outside world, e.g. Carthusians. The monastic rules of the Franciscans dictated that they make the necessary manuscripts on their own. This was respected in manuscripts required for reading and in those of importance to the monastery (e.g. texts on the history of their Order, or their monastery, or their members), yet they strayed from it when liturgical manuscripts were in question; these had to be of high quality (a fine example are the manuscripts made for the Franciscan monastery in Ljubljana from ca. 1492, in the style of Viennese manuscript workshops and the work of professionals. After all, they were the gift from the provincial governor William Auersperg and his wife Margarethe von Kraigh); Golob 2006, p. 29. In his lecture "A la (re)découverte des scriptoria" (11 September

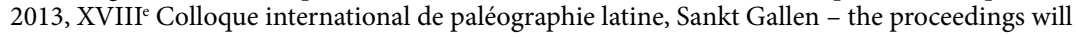


The means that the balance had shifted even further in favour of professional copyists, rubricators, correctors, illuminators, book-binders, and others connected to the subject matter by trade, providing paper, pigments, binding media, as well as model books.

The Middle Ages certainly did not have a patent on anonymity; they wrote down information that they found to be interesting, different, worthy of being documented, and not that deemed as common knowledge and therefore unnecessary. However, we often encounter artists who were so well known in their time that they felt no need to write down their names (or whose signed works have simply all been lost), and it is only the irony of fate that others did not do the same. Despite their large opuses and the accompanying chance to follow many an artist on the basis of their creations - those that are preserved and stylistically recognizable - we can follow their artistic development, yet many of them are today known only by their temporarily assigned names.

Hamon (62) also pointed out the slippery field of determining professions that can be sometimes read in documents, as the 'painter' may not have been an artist, but merely a decorator, an embellisher, who would have added painted ornaments perhaps with the help of templates; similarly, the word sculpsit does not immediately signify an artistic sculpture, it might have merely meant a simple procedure, for example, of a channel, an ornament carved into wood or stone. There were many rather specific words ${ }^{8}$ that marked a phase in the work's progress, or determined the participation share in the making of the manuscript, such as: explicit, scripsit, composuit, edidit, correxit, rubricavit etc. (Battaglia Ricco, 132). The verb is commonly placed in the third person singular - i.e. he explained, he wrote, he composed, he prepared... It would be erroneous to think that the author was trying to distance himself from his creation through such impersonal verb usage, that he was, attempting to hide in the background. This was the common form of self-presentation and is always regarded as a statement in the first person. The mediaeval scribe had similarly reported his own name without hesitation, and Jan van Eyck's formulation of his signature on the painting of Giovanni Arnolfini with Giovanna Cenami should be understood as such: it is a large signature in calligraphic cadels, right in the centre of the visual field, on a white wall, where not a single detail interferes with the name: Johannes de Eyck fuit hic - Jan van Eyck was here, in person. Let it be known.

presumably be published in 2015), D. Muzerelle had listed data on the ever declining number of manuscripts from monastic workshops. Yet we cannot apply this information to the entire European area; it is undoubtedly true for the Parisian area, and likely also the Old Dutch cities, while other towns and regions were catching up to these ratios at their own pace.

8 The most general and common ones are pergaminarius, scriba, scriptor, notator, rubricator, florator, illuminator, ligator etc., which also denominate their particular area of expertise. 
We can also examine the century after that and acknowledge Vasari, who weaved into his Vite de' piu eccelenti pittori, scultori e architettori (1550) ${ }^{9}$ numerous facts about himself, even though he rarely used the word 'I'. Yet in essence, Vasari merely continued the mediaeval tradition of colophons, autobiographies and selfrepresentations. He used his lengthy introduction to promote 'him, the one Vasari, who is knowledgeable in every Art, ${ }^{10}$ and in the mid- $16^{\text {th }}$ century such a presentation, along with linguistic brilliance, is basically a calling card. It is a formal display. In his self-representations - which he does not shy away from even in other parts of his book - he managed to express everything he wanted: his attitude to work. In passing he finds the opportunity to describe how he had managed to astound everyone present at a certain occasion with the breadth of his knowledge; he included memories of his family and his birthplace; he inserted anecdotes describing the moment when the Grand Duke Cosimo de' Medici called him 'my friend;' he had set himself shoulder to shoulder with Michelangelo, etc. Truly, the situation is like a mirror trick where that which is obvious at first glance is less important than what is hidden behind the veiled edge: the usage of the third person singular is not a form of humility for Vasari. On the contrary, it is a conscious expression of one's own worth, pointing to his privileged position in society (Frontisi, 32-33). ${ }^{11} \mathrm{He}$ had produced the most epically spacious auto-novel of the time, creatively dispersing through it the lives of other artists, their creations and contemporary events.

The mediaeval man with a pen in his hand could not present himself to his audience in the same way an illuminator could, where the onlooker could see him at his work on his creation, and see him as the work's creator. ${ }^{12}$ It is more than just

9 Vasari's manuscript is preserved in three volumes, bound in parchment, and were copied by Giovanni Gaetano Bottari (the librarian for cardinal Neri Corsini) and is not an autograph by Vasari himself; now: Rome, Biblioteca dell'Accademia Nazionale dei Lincei e Corsiniana, 29 E 4-5-6.

10 Cf. Pointon, p. 122, who in the short paper "Sense of Self" draws attention to the role of the mirror in Renaissance portraits; the recently published book, Portrayal and the Search for Identity (2012) was not available to me.

11 "A passionate and witty" controcanto to Giorgio Vasari is the Vita di Benvenuto Cellini...scritta per lui medesimo, a fortunately flawlessly preserved autograph; now in Florence, Biblioteca Medicea Laurenziana, Med. Pal. 234(2). The fundamental difference between Vasari and Cellini lies in the position of Vasari as the courtier with the backing of Cosimo de' Medici, and his having created the monumental work on art for the eternal glory and fame of Florence (Benedetto Varchi accepted a similar commission, namely, to write the history of Florence). This was political in nature, a programme that served to solidify the Florentine city-state. On the other hand, we have a very valuable - although biased - description of Cellini as a sort of lone wolf in the Florentine artistic world. For Cellini's autograph see F. de Luca, p. 378-379.

12 A discussion on the painter's or illuminator's self-portrait cannot be opened here, as the understanding of what a recognizable depiction of a person ("portrait") means has changed in the meantime as a result of different valuation standards for monuments of art. I found the account of how, in 1099, Anselmus, later Bishop of Canterbury, was in mortal danger during his travels from Rome to Lyon. He was in danger because the anti-Pope Wilbert had Anselmus's image painted on a wooden panel, so he would be recognized everywhere and would be unable to hide. This is quite exceptional (Lehmann- 
the simple circumstance that only a few copyists were good enough at drawing to be able to paint themselves while at work. It is all dependent on the medium of expression. Much as the painting paints the painter, so too does the word verbalize the wordsmith.

I am dedicating the next few pages to three copyists who by their lineage or their work are connected with Škofja Loka (Germ. Bischofs-Lack) and, most likely, with Velika Nedelja (Gross Sonntag) and Trebnje (Treffen). However, let me first make a distinction between the autograph that is the author's own textual creation and the copyist's autograph that is most commonly found in the colophon. ${ }^{13}$ Autographs are their own field of research, one which is crucial to the research of the creative process, as they are a point of confluence for the stroke of the thinking author as he writes and the end result. ${ }^{14}$

There are no autographs preserved from Antiquity, though we do have some beautiful depictions of pre-Christian authors from those far-removed centuries and even a God the Father writing down the Ten Commandments. ${ }^{15}$ From the Middle Ages there remains a long and gradually richer sequence of original texts by intellectuals and literate individuals, over whose shoulders we can peer as they write letters, chronicles, works of theology, and science, or other muse-inspired creations.

In those mediaeval times autography was always joined by ideography, the act of writing under the author's supervision, often the case due to circumstances like age, ${ }^{16}$

Brockhaus, p. 187, nr. 5840). We cannot imagine today just what kind of a specific, individualized image could have been relayed by a panel painting from ca. 1100, and even less how the facial features would have approached the reality within the Romanesque pictorial principles, or how the painted image would have had to have been in those mediaeval times for the depicted person to have been indisputably recognizable.

13 Sometimes the copyist would have shown a personal touch, when he 'jumped' into a personal commentary in the middle of his copying; it usually is not an interpolation to the text itself, but a reaction to the conditions and circumstances of his work. As an example, I can list the wrathful copyist of the Bible that was in the monastery San Pedro de Roda for several centuries: on the margins of the Book of Esther he wrote that he is copying after a manuscript where the books of the Old Testament are not correctly ordered, and that he has before him folios bearing depictions that are completely out of sequence. Now: Paris, Bibliothèque Nationale, ms. lat. 6, vol. 3, fol. 97r. Cahn, 76.

14 On the topic of autographs as a creative process that mirrors social psycho-dynamics, there exists a substantial body of literature and for the sake of temporal proximity, I would like to drawn attention to the collection of presentations from the XVII ${ }^{\text {th }}$ colloquium of the Comite international de paléographie latine (Ljubljana, 6 - 10 September 2010) under the title Medieval Autograph Manuscripts, etc., wherein is published a selection of a large part of the most relevant literature.

15 Freeman Sandler, ills. 2 and 3.

16 Guibert de Nogent (+1124) was a creative writer for the majority of his lifetime, and his claim to fame today lies in his autobiography and not in his theological treatises. In it he had - old, ill and blind - lamented: sola memoria, sola voce, sine manu, sine oculis. This is all that remained to him: his memory and voice have not abandoned him, but neither were his hands nor his eyes at his command anymore. Garand, M.-C., p. 3 ss. 
or other creative mechanisms, as the majority of mediaeval authors until the early $13^{\text {th }}$ century dictated their texts to their secretaries. An example of this is the manuscript from Narodna in univerzitetna knjižnica (= NUK), Ms 12, with a description of the life and miracles of St. Catharine of Siena: as evident on fol. 100r, the text was copied by a monk named Bernard from Jurklošter (Gyrio/Gairach), who finished his work on May $20^{\text {th }} 1401 .{ }^{17}$ Somewhat hastily, Milko Kos wrote that the glosses next to the text (incorrect, these are in fact additions) were written by Stephano Maconi, the prior of Charterhouse Žiče, himself. Yet this is not Maconi’s autograph, but his ideograph, as his additions were dictated while being written down by his secretary of either German or Austrian descent in letters that bear qualities of south-German writing provenance and not Italian forms. ${ }^{18}$ Perhaps Kos was distracted by the additions formulated in the first person singular: ego frater Stephanus (fol. 75r) and ego quoque frater Stephanus (fol. 95r and 99r). However, with this phrase Maconi had expressed the authenticity of his additions and his presence at the event. ${ }^{19}$

With the establishment of the printing press the way the author's text was transmitted and preserved had changed significantly. Many literary and scientific autographs were lost simply because they were discarded by printers after being used. Those that remain are either the author's preparatory texts (drafts) or were intended to be viewed only in private anyway (letters, commentaries, diaries, testaments, professes).

The expanse of autographs is great in many ways and they have a number of interesting aspects to them. The value of an autograph written by a trader lies in the authenticity of the information it conveys about the history of an economy; the value of a letter between two lovers lies in the formulations of emotional confessions in the context of personal circumstance and societal norms; meanwhile the most attention is given to the autographs of learned and famous people. ${ }^{20}$ The last will be more numerous depending on how much their environments favour intellectual endeavours. Regardless of whether an autograph was written in Latin or a spoken language, each authentic text by an author discloses one's linguistic knowledge and the skill to set it

17 ... explicit legenda sancte Katherine virginis de Senis per manus fratris Bernhardi ordinis Carthusiensis Vallis sancti Mauricii in Gyrio. Et sic est finis. Anno domini $M^{\circ} C C^{\circ} C C^{\circ} I^{\circ}$, feria sexta, XIII kal.Iunii, hora septima...

18 Kos-Stelè 78-82, particularly 81, image on p. 82. - Cf. Raimondo da Capua, Legenda maior in a critical edition by S. Nocentini with a palaeographical analysis, claiming it is written by a "German" hand. Stefano Maconi was born in Siena and educated in Italy, where he lived until 1398, when he was elected to be the prior of Charterhouse Žiče.

19 Kos, p. 81, image on p. 82 is not a reproduction of the gloss on fol. 75r, but the one on 95r.

20 There is an ongoing project of many years in Italy "Autografi dei letterati italiani" whose mission is the documentation of all autographs by Italian men of literature and culture from the High Middle Ages until the $16^{\text {th }}$ century. This documentation (with numerous copies and transcriptions and visual documentation) will be the foundation for future literary, linguistic, philological and palaeographical research. Brunetti (2013), p. 329-338. 
down. Most of them - in the periods of the Late Middle Ages and early Renaissance were capable of writing in at least two types of writing, if not more, ${ }^{21}$ and next to thus cultivated digraphism or even polygraphism there still remained an enormous space for those fleeting, personal, even informal writings. ${ }^{22}$ The term autographum was not known or used in the Middle Ages, it is not listed in any lexicons, and the writers themselves used phrases with which to verify the authenticity of and their personal relation to the text. ${ }^{23}$

And the copyist, the person who had done the work for the payment?He had expressed and introduced himself in the additions and mainly in the colophons. There are not many known examples from the early Middle Ages - also due to the few remaining manuscripts - though they become more common from the $12^{\text {th }}$ century onward, ${ }^{24}$ that is, at the time the monk Bernard had signed himself, most likely while he was a central figure in the manuscript workshop in Stična. He is one of the earliest scribes from Slovene lands whose names we know. ${ }^{25}$ There is also a much greater variety in the formulations of colophons from the mid- $13^{\text {th }}$ century onward, developing along with greater freedoms of civic scribes. The copyists' autographs were joined by those of translators, makers of compilations and other thematic, abridged overviews (Supino Martini, 23-25). To this we should also add manuscripts which were not only evidence of knowledge, but also of need, be it administrative in nature (municipal books, books of fraternities, statutes, family chronicles, various records, etc.), or in matters of content (copies of literary, scientific and musical works), and these are often works that are defined by the date and the name of the person doing the work. These two facts emphasise its documentary value and are a guarantee for quality.

21 Cf. contributions by Z. Hledíkova and O. Merisalo in this journal.

22 In monastic scriptoria it was, until the end of the $12^{\text {th }}$ century, expected from scribes that they stick to the style of letters in line with monastic traditions. Due to regional and institutional canons of writing, there is a much more subdued expressiveness of autographs present than is the case from the mid- $13^{\text {th }}$ century onward.

23 It is difficult to forget the touching words by Peter of Poitiers, from when he was the secretary and friend of the abbot in Cluny, Peter the Venerable; in a letter (nr. 128) he had apologized to the great head of the monastery for his irregular letters, due to illness: Ignoscite pauperi cartae et vili scripturae, quoniam et propter absentiam vestram et funera frequentia, pedisque mei aliquantulam adhuc debilitatem, vix aliquid facere libet. Long, p. 442-443.

24 Supino Martini, p. 16 ss.; yet we have to acknowledge that this estimate does not apply equally to all of Europe (due to Mozarabic elements on the Iberian Peninsula, there are numerous colophons, rich with names, in the $10^{\text {th }}$ and $11^{\text {th }}$ centuries), as various regions had their heydays in different periods. The $12^{\text {th }}$ century was undoubtedly a time of literary wealth in south-German, Mosan, Burgundian and central-French areas.

25 Lectori. Bernhardus monachorum Christi minimvs. Quocies hoc commentum a me exaratum ad legendum sumes queso ut memineris laboris mequae iuuare studeas tuębono orationis. Gregorius Magnus, Libri moralium, Ljubljana, NUK, Ms 8/II, fol. 2r; Kos-Stelè, p. 24. We should also add the names of (En)gilbert and (Nicolai / Willermus), who had introduced themselves at about the same time, ca. 1180, 'equipping' their portraits with their names in the manuscript from Stična by Aurelius Augustus De civitate Dei, now Vienna, ÖNB, Cod. 650. See Golob, 1994, p. 150-163. 
Dedicatory and ownership inscriptions are also counted among autographs. ${ }^{26} \mathrm{We}$ can see some fine examples among the manuscripts and prints that were owned by those Slovene Humanists who had spent their careers, or most of it, as scientists, professors, or ranking diplomats in Vienna. ${ }^{27}$ Many manuscripts turn out to be a collection of personal writings; to cite an example, a codex with works by several Antique authors (today Vienna, Cod. 3210). ${ }^{28}$ It was bought by Tomaž Prelokar (Berlower) of Celje and presented as a gift, in 1471, to his pupil, the then 12-year-old Maximillian, successor to the throne and future Holy Roman Emperor. The manuscript, written in litterae bastardae by a professional copyist, is filled with Prelokar's glosses, which are written in current script with an individual touch, and - interestingly - Prelokar's dedication and Maximilian's addition to it Maximiliano duci Austrie huius Terencii usum dedit doc(tor) Thomas de cilia anno domini 1471, which are written in early bookhand. The pupil's writing has many features similar to that of the teacher; both are very sinuous, and despite an effort to give the dedication and its grateful acknowledgement features of formal excellence, it fell short of the mark.

Included in colophons and additions in German lands - more often than elsewhere in Europe - was information about the time in which the manuscript was made. This was often announced with the words anno Domini, or ab incarnatione Domini, for the sake of preserving older formulations. Even in the afore-mentioned Prelokar manuscript Maximillian had used the phrase in the year of our Lord...' These dated colophons are a firm basis for a paleographical and codicological analysis, while other pieces of information may uncover the circumstances, the commissioners, readers, the origin of the copyists, etc., which in turn is a starting point for prosopography.

One cannot be too careful when reading colophons, and, as A. Derolez warns, the many colourful tones and forms of verse in them had enchanted many mediaeval experts into conclusions about the copyist's mood and his linguistic versatility. Both can be an illusion, according to Derolez, as the phrases used in colophons are often variations on Latin proverbs and do not express the copyist's inner thoughts. ${ }^{29}$ This

26 See the contribution by S. Svoljšak in this journal.

27 Simoniti, esp. p. 147-154.

28 Vienna, ÖNB, Cod. 3210, the manuscript contains comedies by Terentius, a copy of his epitaph, Petrarca's essay on the life of Terentius, commentary to his comedies and excerpts from the Heroides by Horace, etc. http://data.onb.ac.at/rec/AL00177950.

29 More honest accounts of such personal confessions are possibly preserved in autobiographies or insertions of such confessions in other literary works. From those texts that were created in monasteries in Slovenia, the most interesting are the accounts of personal experiences, written in NUK, Ms 40, which contain the verses of the monk Syferid, who lived in Jurklošter, but originally hailed from Suabia. Literary-historical analyses have shed a fair amount of light on its contents; we should add that we are dealing with a correct copy of Syferid's verses (from the second quarter of 
provides reasonable doubt into claims of honest feelings of sin and penitence lying behind the humble formulae and anonymity, ${ }^{30}$ and about whether those riddle signatures (which need to be read back to front), or witty sentences (which have the syllables of a name hidden within), are truly cases of exceptional ingenuity. ${ }^{31}$

\section{Three subscriptions}

There is certainly no lack of copyists' colophons from the mid- $15^{\text {th }}$ century, though we must admit that only a few of the names appear more than once. ${ }^{32}$ Often the personal name is accompanied by a locational name, which primarily means that the copyist had done his work away from home. The three selected examples are exactly such and the scribes presented themselves in the colophons thus:

${ }^{* * *}$ Martin of Loka: Wien, ÖNB, Cod. 2821, fol. 157r (ill. 1):

Anno domini Millesimo Quadrigentesimo sexagesimo sexto finitus est liber per manus Martini de Lakch In die sancti Valentini.

In the year of our Lord one-thousand four-hundred and sixty-sixth this book is completed by the hand of Martin of Loka on St. Valentine's Day.

${ }^{\star * \star}$ Matjaž Jurčič of Kapela: Wien, ÖNB, Cod. 14.474, fol. 107r-107v (ills. 2 a and 2 b): Deo gracias. Amen. Finito libro frangamus Ossa magistro. Expliczit hoc totum; infunde, da michi tottum!(!) Hie hat daz puech ein ende. Gott vns vnser laid in frewd wende! Explicit puech Allexander per manus Mathiaz Iurchicz Aus der Capellen. - O diuez divez! Non omni tempore viuez. Sy tu sentirez, quo tendis et vnde venirez, Nuncbam riderez, sed omni tempore olerez. Mortus est diuez, Sepultus in inferno.

the $13^{\text {th }}$ century), and that the codex does not contain the poet's autograph from ca. 1260 . See the codicological description by F. Lackner: http://www.ksbm.oeaw.ac.at/kataloge/SI/cat_SI.pdf and the codicological-palaeographical dependence to the essay Stimulus amoris, from ca. 1340.

30 For example, Nomen scriptoris non pono / Quia me laudare nolo. // Scriptor qui scripsit / Cum Christo vivere possit. etc. Derolez, 41.

31 Ljubljana, Archives of the Archbishopric (= NŠAL), Ms 13, fol. 93r: the scribes's name is written mirror-inverted: Explicit biblia pauperum per Iohannem; NŠAL, Ms 12, fol. 73v: the colophon hides the name of the scribe, Iacobus Nicolaus Drzco, with emphasis on the interwoven letters that read as 'Amen': ...AiacobusMnicolausEdrzcoN... ; NŠAL, Ms 14, fol. 87v: The copyist is Iacobus Crisvitsch de Kraynburga: Explicit martyrologium per Ianavaconovobumivm Crisnivisuinivitsch deneve Kraynavanbumivrganava anno domini millemo quadrigentesimo vigesimo quarto in vigilia purificationis... NUK, Ms 140, fol. 223v: The copyist Tristan had hidden himself inside the instructions to the puzzle: Si tris ponatur et tan simul associatur et nus addatur, scriptor huius sic uocatur...; a reproduction of Tristan's signature: Golob, 2010 b, p. 32. Derolez, 44, cites a similar puzzle: Si Io ponatur, et han simul apponatur et nes addatur, qui scripsit ita vocatur (=Iohannes).

32 Let me mention the copyist Mathia Maselhart de Alczeia, who left his signature in a number of manuscripts from Charterhouse Žiče, and, at least judging by his style of writing, I can assume that he had stopped at the monastery in Bistra as an itinerant manuscript worker. Golob, 2010 a, p. 193. 
The book is done, let's break the teacher's bones. Thus it is explained; pour it, give me a drink! Here is the book's ending. God, turn our suffering into joy! The book of Alexander is explained by the hand of Matjaž Jurčič of Kapela. - O, rich man, rich man! You will not live forever. If you could feel what is preparing and is yet to be, you would never laugh, but always sigh. Dead is the rich man, buried in Hell.

${ }^{\star * \star}$ Herman Talner of Trebnje: Chicago, Joseph RegensteinLibrary, Ms 978, fol. 178v (ill. 3 a):

Das puch ist geendt vor den durch denn hermanne Talner von treffen und gehort dem edeln und vesten Ludweigen von Kosyagk am sambstag vor sand michels tag in dem iar als man schreibt nach xpi gepurdt vierzehen hundt' und darnach in dem LVI Jare. Deo gratias.etc.

This book was completed by Hermann Talner of Trebnje, and belongs to the noble and firm (respected) Ludvik of Kozjak, it was completed on the Saturday before St. Michael's Day, in the year after the birth of Christ numbered fourteen-hundred and another LVI years. God be praised, etc.

Ms 978a, fol. 259r (ill. 3 b):

Amen. herman talner etc. Anno ic lvj.

Amen. Herman Talner etc. In the year of Christ's incarnation LVI.

The codices of which these colophons and scribes speak were written in approximately the same period, namely, in the third quarter of the $15^{\text {th }}$ century. All three of them had set down their names and the place (or major town near their birthplace) where they had grown up, and all three of them had lived from writing and copying, or at the very least it represented an important part of their incomes. The first penned his colophon in Latin, yet he wrote the texts in German and Slovene; the second constructed the sentences in the colophon in Latin, German and Provençal, while Seifrit's epic on Alexander is completely in German; and the third man wrote the colophon in German, as well as both of the main texts, while a few passages are in Latin. We hardly know anything about these three men; we have no documents, no information of their birth from parish books, we do not know which schools they attended, etc. We can therefore only judge their work based on these remaining copies (to which we could add to with an examination of archival material - and a paleographical analysis - another document or two and compile a broader image). 
Martin of Loka received the commission for this manuscript ${ }^{33}$ from the Lord of Brdo near Kranj; the owners of this court were - according to Otorepec (Otorepec, 3) - "lesser knights, called noble Egg (or Eck, Ek, Eghh, Ekker, etc.), sometimes also Ekker. As in German the word Egg corresponds to the Slovene word Brdo, these nobles could also be called 'of Brdo' or 'Brdski'. The first of them, a fellow named Jakob Brdski, is mentioned as early as 1420." At that time, Vid Jakob had married the noblewoman Uršula Liemberg, thus beginning the rise of this line of nobles (Slana, 23). The Brdski noblemen had become feudal vassals of the Counts of Celje, after the line of Ortenburg family had died out. ${ }^{34}$

The commissioner is not named directly in the manuscript, ${ }^{35}$ though he is announced by two heraldic crests, set one atop the other: the larger crest belongs to Henrik of Brdo and the smaller one to his wife Margareta/Marjeta Vogrska, also of Hungersbach. ${ }^{36}$ Together with Henrik $(+1509)$ the family had entered high nobility. In between the ending of the capitulare and the beginning of the text proper, there is the depiction of the crests on fol. 11r that extends across the entire height of the writing space: above is the silver-and-black crest of the nobles of Brdo, with a checker field on the heraldic right and a log on the left, while below is a silver-and-red crest (that is smaller and already within the writing field) of the nobles of Vogrsko, bearing an upturned crescent moon. ${ }^{37}$

The manuscript was in all likelihood commissioned by Henrik of Brdo and its contents are somewhat surprising. The majority of the manuscript is made up of a book discussing several chapters of canon law (fol. 1r-157r); the work of Johannes of Freiburg was completed with a commentary in around 1300 by his successor and head of the Dominican monastery, Berthold of Freiburg. Martin of Loka had signed himself at the end of the text, and he was more than just a flawless copyist, with a steady, unerring hand, but was also (on the basis of a textual analysis by Weck, p. 200) a man of learning. The final pages (fol. 157v onward) of the manuscript contain

33 The manuscript is quoted in several publications from the mid-19 $9^{\text {th }}$ century onward; the most recent codicological description (F. Lackner, publ. 27 June, 2008): http://manuscripta.at/m1/hs_detail. php? ID=6098.

34 Žontar, p. 33, states that they had started out as lesser feudal vassals to the Counts of Celje; in 1436 Frederick II gave Jakob Ecker several farmsteads in Prebačevo, and one-tenth in Predoslje.

35 Radics, p. 13: "This manuscript is [important] for us, as it is from Loka, and surely belonged to a monastery..." He must have been led to believe that this manuscript belonged to a monastery, as it contains the canon law, and that such topics belonged in an ecclesiastical environment.

36 Unterkircher (1976), p. 218; Weck, p. 201-202 with earlier literature from Valvasor onward. For a colour image see Golob, 2010 a, p. 14, ill. 1 and Golob, 2011, p. 195.

37 This sort of crest of the Lords of Brdo is depicted in numerous places; on the copy of the crest from the ossuary chapel in Kranj the design remains the same, yet the eagle, the helm and the draperies are mirror-reversed. Slana, 2009, ill. on p. 23; the drawing is kept in Graz, Landesarchiv, Attems Collection. 
several short texts. The first is an astronomical-astrological prediction on the fate of Man according to his date of birth; the text is in German, while the names of the months are in Slovene. This is followed (fol. 158r-163v) by a series of short texts in a combination of Latin titles and German translations and/or explanations (a Jewish oath, on the execution of the oath, a dialogue between teacher and pupil on Communion and Baptism, on the influence of fasting, the influence of Hail Mary, on general prayers, the Ten Commandments, on hellfire, on Computus, on caring for horses).$^{38}$ Viewed as a whole, the lengthy treatise on confessions is a rather important chapter of canon law and might have been studying material in an ecclesiastical environment, or the reading material of a well-educated person with numerous obligations connected with justice; the other texts (such as the Jewish oath) are a mirror of the dilemmas one faced as a feudal lord. The codex was re-bound in the $19^{\text {th }}$ century, when some of the folios (in this case half-bifolios) were incorrectly placed, with another 15 or 16 folios missing, containing the final entries for the letter $\mathrm{D}$ and the majority of those for the letter $\mathrm{E}$, mainly all the entries pertaining to weddings (= die Ehe; Weck, 199-200).

The question of whether this work in any way highlights the circumstances in Kranj and its surroundings, on Brdo, Smlednik, in Naklo, etc., does not have an unequivocal answer. It appears to be more a case of the Lord of Brdo (assuming he had commissioned it for his personal needs) wanting to be better versed in ecclesiastic and civic matters that might pertain to him. According to Weck, this text is based on a model book that is unknown to us today; therefore it is significantly different from other, "standard" copies. Perhaps, the additional explanations, interpolations even, were added by Martin of Loka himself. The manuscript might have also been an expensive gift, as it is the only one among the (at least) 105 remaining manuscripts with this treatise of Berthold of Freiburg ${ }^{39}$ that is decorated with painted initials. Perhaps one might consider the brother of Henrik of Brdo, Pancras, then parish priest in Kranj, as a potential recipient, yet this should remain only an assumption, as the brothers had a mighty argument later on.

Martin of Loka (Illustration 1) was excellent at what he did and the codex was most likely made in Vienna. This is firstly confirmed by his self-introduction as "Martinus de Lackh," secondly by his linguistic determination of a "Bavarian-Austrian dialect," and thirdly, underlined by his painted decorations, which were added simultaneously or immediately following the copying process and bear stylistic similarities to Viennese illumination from the vicinity of Ulrich Schreier and his workshop.

38 Esp. Menhardt, p. 385-387.

39 Cf. http://www.handschriftencensus.de/werke/788. 
Martin of Loka undoubtedly came from a Slovene-speaking environment; the names of months written on his native language [Prosyncz, Setstzan (svečan/February), susecz, maly trawen, weliky trawen, bobouczwett (June), maly serpan, weliky serpan, Poberuch (September), listognoy (October), kozowpersthk (November), Gruden $]^{40}$ do not appear to be a sticking point for his pen; nothing was crossed out, and no errors were scraped off. The assumption that these were not the only words written in the language of Carniola is not mere conjecture. Short descriptions of the fates that await children born in a particular month, along with a text on planets (fol. 163v), set him among the group of poets using astrological verses in German, and these texts are also repeated in a manuscript thatis kept in Rome today. Martin of Loka completed this codex (Seifrit's text on Alexander) only a month after Berthold's legal-moral handbook. $^{41}$

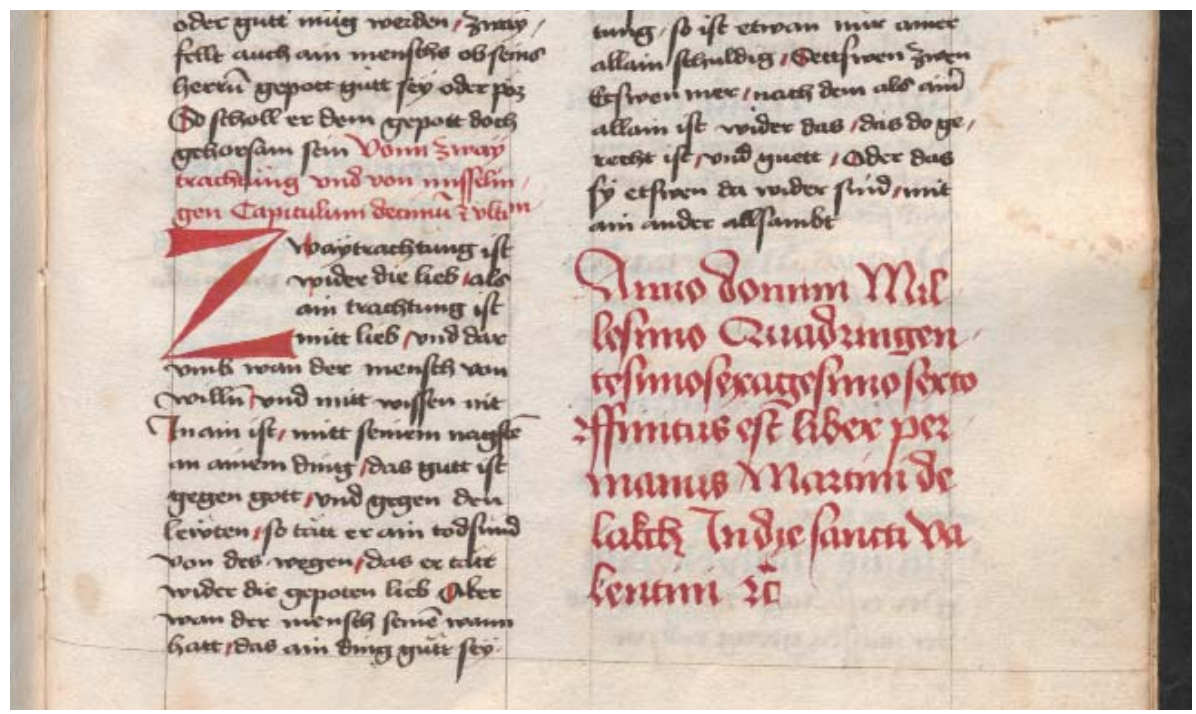

Illustration 1: Wien, Österreichische Nationalbibliothek, Cod. 2821, fol. 157r, colophon, written by Martin of Loka (Martinus de Lakch).

While copying Berthold's legal treatise, he was undoubtedly using an unknown model book in an Austrian or Lower Austrian-Bavarian dialect, and we can easily imagine that he would have obtained the model manuscript in one of the numerous ecclesiastic or scholarly libraries (or in the early collection of the University Library) in Vienna. The Viennese scriptorial ambient is confirmed also by the illuminated

40 Texts are listed in their entirety by Radics, p. 13-14.

41 Weck, p. 201. Basic data on the manuscript: Rome, Biblioteca dell'Academia Nazionale dei Lincei e Corsiniana, Cod. 821 (shelf-mark: 44 A 6), 129 fols. Contents: fols. 1r-126v: Seifrit: Alexander; fols. 127r-128v: On the seven masses, On Austrian lords (a later addition), signature on fol. 126v: per manus Martini delakch; I have not yet had the opportunity to inspect this manuscript. 
decoration: the heraldic page in particular is an excellent contribution to illumination, and the comparative opus of Ulrich Schreier and his workshop can be clearly felt. The Lombards are without any pen-work decoration and are merely functional elements. The influence of Schreier-style is implied only within the painted initials, namely, through the shapes of infilling leave-fillers and the convincing, plastic toning, scroll sprouts, and spindle-like blossoms with diaper pattern in the inner fields etc. However, for Schreier's (though not only his) pictorial language the inclusion of faces or unusual physiognomies within the initial composition is also quite characteristic; there is a green face in the inner initial field of the letter $\mathrm{D}$, and it appears as if a sylvan spirit is looking out at us (fol. $37 \mathrm{v}) .^{42}$ Some of the initials stand out as an achievement, while others are fairly meagre and it is more than obvious that the manuscript was created in a workshop with several illuminators working at different levels of skill. ${ }^{43}$

Neither German nor Slovene gave Martin of Loka any difficulties, even though he signed himself in Latin, demonstrating his fluency in all three languages this way. He was also skilled in the use of different forms of lettering: the capitulare and the text up to fol. $70 \mathrm{v}$ were written with a fine pen in current script by another copyist, while Martin used from fol. 71r until the end a form of looped litterae bastardae. He wrote his colophon in a form of early bookhand whose tall line spacing is impressive; he used it in an entire explanatory segment of the tree of consanguinity (fol. 96r-96v) along with the names (only names, no explanations) of the months in Slovene and in German (fol. 157v). He was a man of great linguistic and graphic knowledge, and through this knowledge we can also ascertain his knowledge in law and theology. He added to this codex at least 177 marginal glosses in Latin (we have no data on the glosses on the missing folios) that do not directly pertain to canon law, but deal with morally-theological questions and practical issues. He backed up his comments by citing several authorities on canon law, and there are also two other names that appear in the marginal glosses: Petrus and Gilo, who are - as is often the case - fictional characters entangled in a discussion with questions and answers in order to explain certain professional dilemmas in simple terms. ${ }^{44}$

42 The field with both crests is $245 \mathrm{~mm}$ high (folio height is $290 \mathrm{~mm}$ ), otherwise the fields for the painted initials are approximately 23-47 mm high, with scrolls spanning up to $190 \mathrm{~mm}$ in height.

43 Along with the heraldic page on fol. 11r, the better initials are D (37v), I (74r), L (90r), M (96r with wonderful nuancing of leaf fillings), $\mathrm{N}$ (103r with its body in white-and-pink tones and large blossoms), R (110r, a large initial with vines, ending in spindle-like blossoms), V (140v with an interesting escalation of yellow, orange, red and gold, in contrast with the black inner field, where "tracery" is lined in gold ink); particularly original are the initials K (77r, which in its black-and-gold contrast looks as if it is cut out of a golden plate) and S (117v, which reminds us of Schreier's leaf patterns on bindings, due to its flattened ornamentation); the initials $\mathrm{H}(71 \mathrm{v}), \mathrm{O}(103 \mathrm{v}), \mathrm{P}(104 \mathrm{r})$ and $\mathrm{Z}(154 \mathrm{v})$ are, however, quite modest in their compositional premise and thus in their execution. For Schreier cf. Michaela Schuller-Juckes, 2009. 
In the colophon of the subsequent of the other selected manuscripts is a description of how the epic of Alexander was completed “... by the hand of Matjaž Jurčič of Kapela.” The verses of Seifrit's epic of Alexander are written in a single column, due to the narrow, halved dimensions $(296 \times 106 \mathrm{~mm})$. The pages also were not set with the usual frame-ruling; there is only a half-frame, and therefore the verses are only bordered by a vertical frame-line on the left and not also on the right side.

There is also not much information regarding the commissioner of this manuscript and assumptions about this are rather broad: since 1861 the manuscript has been kept in the manuscript collection of the Austrian National Library in Vienna, when the principal custodian of the Royal Library at the time, Dr Theodor von Karajan purchased 339 manuscripts that were on offer by the Central archives of the Teutonic Order in Vienna. ${ }^{45}$ There are 105 mediaeval manuscripts in this group ${ }^{46}$ (from the $12^{\text {th }}$ to the $15^{\text {th }}$ century), and about 40 of those are of Ljubljana provenance. ${ }^{47}$ As a group bound by location of origin these manuscripts differ from the others by their bindings (mostly dark-pink leather, and blind tooling), and some of them contain signatures of copyists and commentators from Ljubljana and White Carniola (Bela krajina) who did not present themselves as brothers or fathers of this order. There is no reason not to think of Matjaž Jurčič as a "freelance" copyist who had offered Seifrit’s epic - a popular piece of literature in the Austrian-Bavarian areas at the time - to a particular reader or to the Teutonic Knights directly. But where? In Ljubljana or in Velika Nedelja? We have no data that could imply an answer to that question. There are two places with the name "Kapela" near Velika Nedelja (not far from Radenci and on Pohorje), but that is the case also near Ljubljana. Yet "Matjaž" is a Slovenian form of a name that is influenced by the Hungarian language - and Hungary is closer to Velika Nedelja than to Ljubljana.

Why might he have been a freelancer? Two details hint at this, the first is the shape of the book, and the other is the colophon. In modern catalogues of manuscripts in German, there are 18 units with Seifrit's text of theAlexanderepos, ${ }^{48}$ all of which - with the exception of Jurčičs book - are a part of, or the entirety of a codex, with fairly standard dimensions of the book-block being a ratio of 3:2, the 'norm' of manuscripts of the time. This manuscript stands out on account of its tall and narrow format of 296

45 For the history of the intent to sell, purchasing and documentation, cf. Lackner, 1998, p. 17-33.

46 A list with shelf-marks and suggested dates: Lackner, p. 26-33.

47 This is merely a summary evaluation based on a relatively rapid examination of a larger number of manuscripts. For now it remains unknown when and why these manuscripts would have been moved from Ljubljana to the Central Archive of the Teutonic Order in Vienna. 
x $106 \mathrm{~mm}$ (approx. 3:1.1), due to the paper sheets having been folded vertically again; ${ }^{49}$ there is a total of 105 folios. This means that he was conservative with the amount of paper at his disposal and he continued the approach on the writing field by leaving narrow spaces on the margins and dense writing. His codex has only 107 folios (only 5 codices have fewer), making it lighter than others simply because less paper was used. Did he have the travelling reader in his mind, one that wanted a light and handy book at his disposal?

He would not have been the first to consciously alter the shape with a specific type of client in mind. We know how well Boccaccio was aware of what types of books buyers wanted and he adjusted the copies he made accordingly; one only needs to look at his graphical experiments and his books' dimensions. He was marked by Armando Petrucci as "a master in control of various shapes, not only in writing, but in the composition of sentences and the design of pages as well" (Petrucci, 514). Petrarca also tried out various book formats and began with a "publishing campaign," 50 by designing the format of the codex and the writing field with his reader in mind. We should also give a nod to the act of reading aloud in front of an audience, which would be slow and accentuated according to its contents, especially if the narration included several voices, or roles (Battaglia Ricci, 139): short lines (in the half-width format) are practical in keeping the eye on the right track while reading, without causing it to skip a line. To choose the design of a manuscript, to control the arrangement of the text on the paper's surface - that is undoubtedly an authorial work.

The adventures of Alexander belong among texts of a secular nature that have a chivalrous accent and are a good match for the character of the Teutonic Knights; the presence of this text within the Order's halls would not have been a disturbance for the members' social status and mission. We should also mention that other examples of Seifrit's Alexander are bound together with other texts of equally secular nature, even if they are not similar in terms of content. ${ }^{51}$

The colophon is unusual for the area of Austria-Carniola-Styria (Illustration 2a, 2b). Not for its length, but its sombre wittiness, which is, according to Reynhout

49 Other manuscripts with the same text, having standard dimensions, measure usually $208 / 215 \mathrm{x}$ $285 / 300 \mathrm{~mm}$.

50 This very expression was used specifically for Petrarca by L. Battaglia Ricci, p. 138.

51 Manuscript from Chicago: Österreichische Chronik von den 95 Herrschaften. Codex from Gotha: Heinrich von München: Weltchronik; Stricker: Karl der Grosse; Otte: Eraclius. Codex from Munich: Gregor Hayden: Salomon und Markolf; Johannes von Tepl: Der Ackermann aus Böhmen; Elsässisches Trojabuch; Gesta Romanorum. Manuscript from Prague: second version of the book on chess. Vienna, Cod. 2881: Suabian mirror, Handbook for household, Hartmann von Aue: Gregorius; Wirnt von Grafenberg: Wigalois. Vienna, Cod. 4212: Leopold von Wien: Österreichische Chronik von den 95 Herrschaften; Johann Seffner: Ain ker von dem streitten. Codex from Lütettsburg: Elsässisches Trojabuch; Hans Schober: Secretum secretorum. 

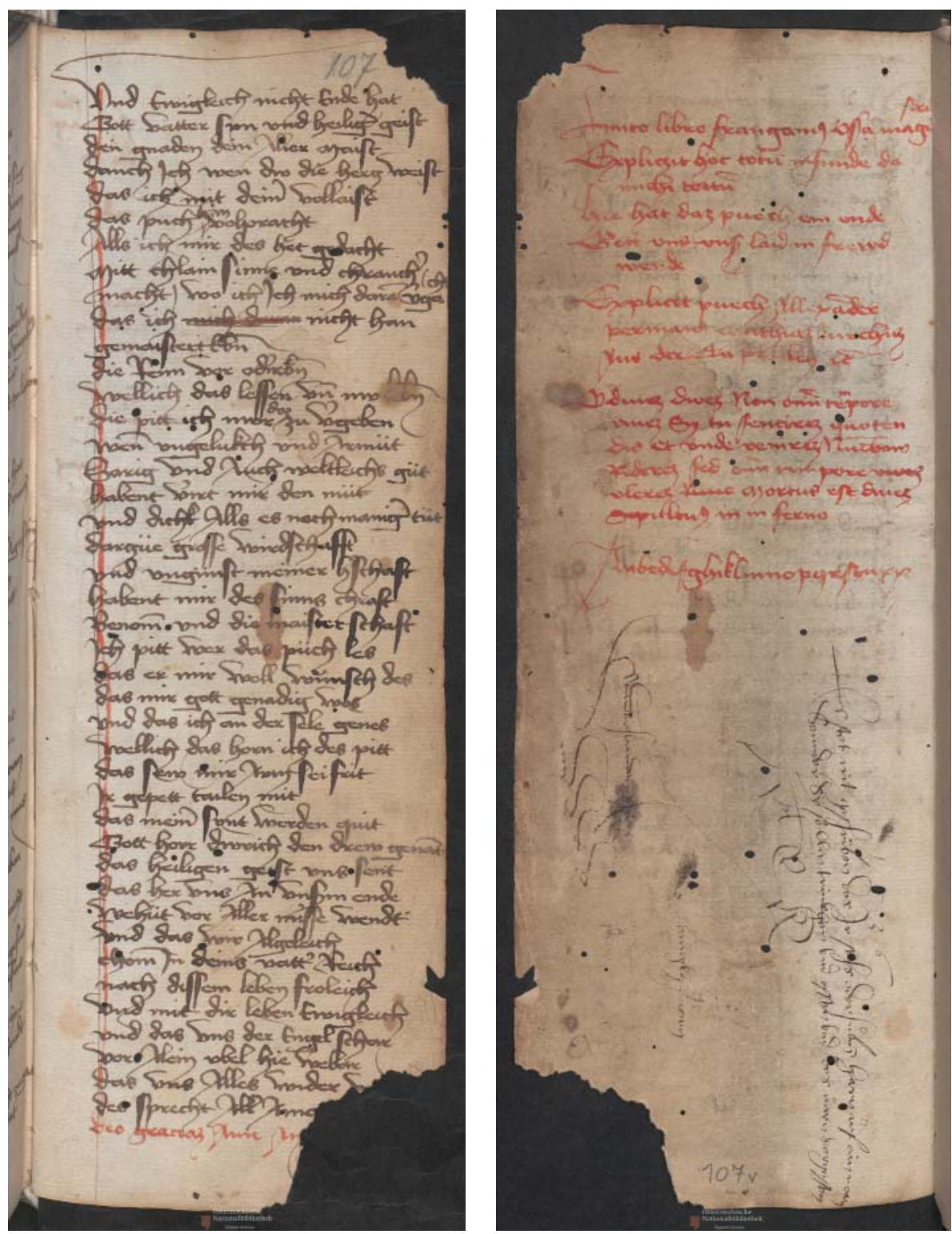

Illustration 2a: Wien, Österreichische Nationalbibliothek, Cod. 14474, fol. 107r, final part of Sifrit's Alexanderepos.

Illustration 2b: Wien, Österreichische Nationalbibliothek, Cod. 14474, fol. 107v, colophon by Matjaž Jurčič of Kapela (Mathiaz Iurchicz aus der Capellen). 
(A, p. 320-321), more at home in France, especially Provence - that is, in places that were more open to the lyrical influences of Catalan and Italian lands, partly also due to the Pope's presence in Avignon. The very first line - “...Let's break the teacher's bones"- gives rise to thinking of a person who used to work for a master (which, in turn, does not mean the copyist is his student), but now, finally free, no longer cares about him. ${ }^{52}$ And, naturally, without the master looking over his shoulder (!) he immediately commits an error: Infunde, da michi tottum...; the last word should be potum (= potus), a drink. ${ }^{53}$ The verse, God transforming suffering into joy, is most likely a popular saying, or a part of a song. Continuing in Provençal, he, interestingly, comments on the rich man's carefree attitude and his forgetfulness of the hell that awaits him. These words bring to mind the dramatic depictions of poor Lazarus and the rich man, of the infernal terrors that await the unjust, etc. Such scenes are common for the sculpted decorations of churches in France. The most impressive of those images would have been looking down upon passers-by from atop churches that stood along pilgrimage roads. The impression might be incorrect, yet it seems that Matjaž Jurčič had seen and heard about the motifs of Biblical sins in southern France. Perhaps he had been on a pilgrimage to Santiago de Compostella, absorbing through lessons and poems the imagery of church façades in Autun, Conques, Santiago, etc. Along with the visual imagery went the southFrench words, written as he had heard and remembered them. This colophon is a verbal pastiche of anunusual kind.

It was in the $13^{\text {th }}$ century that this style of humorous satire-parody had its moment in the colophons from France, and this continued at least until the mid$14^{\text {th }}$ century. At the time, before the onset of the black plague, one could gather a glimpse of this grotesque lack of restraint in the margins of manuscripts, where various creatures appeared around the frame-lines. Without institutional rules, and as a free artisan, Matjaž Jurčič allowed this humour to live on in this manuscript as well.

The third colophon proclaims the exact time at which the final full stop was made in the manuscript, by Herman(n) Talner of Trebnje, on September $29^{\text {th }}, 1456$, and that the book belongs to the noble and respected Ludovicus of Kozjak. ${ }^{54}$ In this case, the

52 Reynhout lists several similar satirical versions; he comments on a colophon identical to Jurčičs, as well as the following: Finito libro frangamus texta magistro in the sense that they throw books at the teacher's head. Reynhout, p. 127.

53 Reynhout titled the chapter on such colophons "Le Temps des écoles: Explicit expliceat ludere scriptor eat."

54 On the manuscript's history and the relevance of its texts, cf. Golob, 2005, p. 77-95. 
copyist assists us by providing the name of the commissioner, who undoubtedly had to have been a man of broad knowledge, who would likely also have had an enviably well-stocked library, or his choice of manuscripts would have been something other than the two long texts, the Austrian Chronicles of 95 Seigneurs, and Seifrit's epic on Alexander. ${ }^{55}$ Castle Kozjak and its lords were described by Valvasor, and one can find a lovely outline drawing of this castle in Valvasor's sketchbook. He mentions a few historical details about the Lords of Kozjak from 1274 onward, with the last of the line being the afore-mentioned Ludvik (Illustrations 3a, 3b):

In the year 1475, the owner of the same (castle), Lord Ludovicus of Kozjak, had fallen into Turkish hands, and only after the payment of an exorbitantly high ransom was he released, in 1476. Since the writer of the 'Ehrenspiegel'56 of the royal house of Austria mentions two thousand gold pieces, it can only mean that he was valued to that amount by the Turks. After his release and return, he had been waning visibly every day, nay, even every hour, and it would not be a misjudgement that the Turks had paid him a final compliment and gift with a slow acting poison. For he was a knight of virtue; a thorn in the Turkish eyes. It is therefore my judgement that he was the last of his name and lineage, having found no one of his family since then... (Valvasor, XI, 314-315).

He was a man of virtue, in possession of a fine library. The first pages of the codex contain the literary work (formerly attributed to Leopold von Wien) Austrian Chronicles of the 95 Seigneurs; this was an important piece of reading material throughout the entire $15^{\text {th }}$ century, as it was sort of political expression of the Habsburgs in a time in which they were building up and fortifying their positions in all areas (Uiblein, p. 716-723). 51 copies remain, ${ }^{57}$ the latest being from the $17^{\text {th }}$ and $18^{\text {th }}$ centuries, which makes for proof of this narrative's longevity. There are versions in German and Latin, and the early examples are mostly text-only; others have depictions of historical events, ${ }^{58}$ and still others are decorated with initials, with the crests of individual holdings, or images of their most notable rulers set at the beginnings of individual chapters. ${ }^{59}$

55 Golob, 2005, particularly p. 90 onward; Golob, 2011, particularly p. 194.

56 Valvasor refers to the thesis by Jakob Johann Fugger; from a comparison of footnotes, one can say that he was reading the 1668 edition. On p. 826 there is a description of the "third invasion of the Turks into Germany," which was in August of 1475.

57 Two of these examples are fragments, some of the texts are written in the form of excerpts; the complete list and relevant information is available at: http://www.handschriftencensus.de/ werke/1882.

58 For example, Bern, Burgerbibliothek, Cod.A 45, where the drawing on fol. 66v represents the coronation of Count Meinhardt of Görz (Majnhart Goriški) at Zollfeld (Gosposvetsko polje).

59 Katalog der deutschsprachigen illustrierten Handschriften...there are several manuscripts of the Austrian Chronicles represented with their illustrations. 


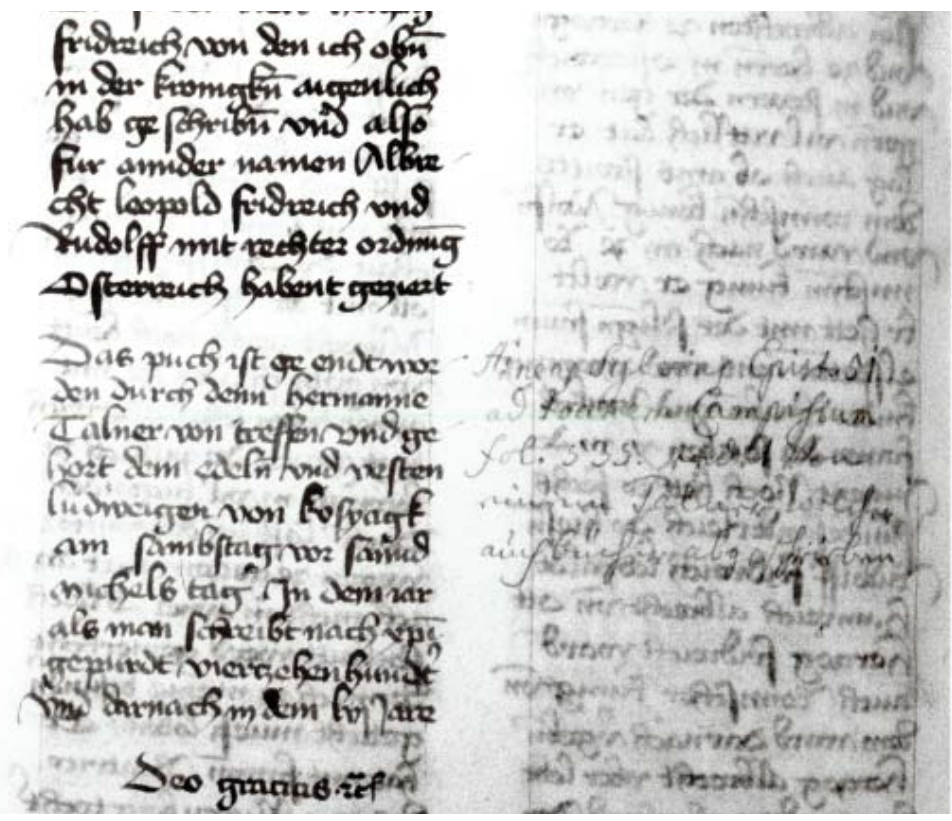

Illustration 3a: Chicago, Joseph Regenstein Library, Ms 978, fol. 178v, colophon by Herman Talner of Trebnje (Hermanne Talner von treffen) at the end of Austrian Chronicles of 95 Seigneurs.

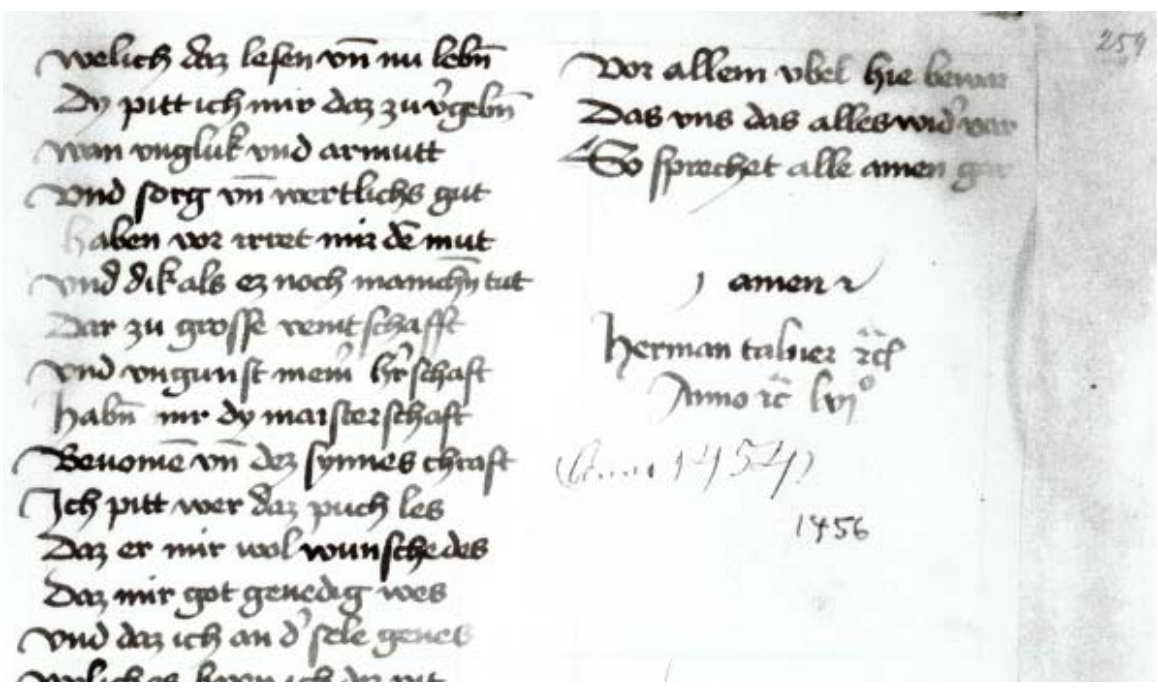

Illustration 3b: Chicago, Joseph Regenstein Library, Ms 978a, fol. 259r, colophon by Herman Talner of Trebnje (Hermanne Talner von treffen) at the end of Seifrit's Alexanderepos. 
The manuscript for the Lord of Kozjak is important in that it belongs to an older version: in his crucial edition, Joseph Seemüller ${ }^{60}$ stated that the book, after which the copy by Herman Talner was made, had to have had a date earlier than 1453. Back then Frederick III of Habsburg had commissioned the famous Coat-of-arms wall (Wappenwand) in the castle church in Wiener Neustadt, while also citing a codex from 1448 that was known as the Austrian Book of Arms (Österreichisches Wappenbuch). The design of the Book of Arms was influenced by the crests of real and fictional holdings in the Austrian Chronicles of 95 Seigneurs. ${ }^{61}$ This codex must have been very important to the historic-dynastic pretensions and discussions at the Austrian court. The archetype of the Chronicles of 95 Seigneurs did not yet have a heraldic page and neither is there one in the manuscript from Kozjak; Herman Talner had not left any space for any crests at all. This can be seen as one more piece of evidence of his having had an early textual version as his model book. After the Coat-of-arms wall had been built in Wiener Neustadt this complex of symbols became the visual carrier for the stately and genealogic ideas of Frederick III, an expression of the Habsburgs' political aspirations and it can be found in all sorts of monuments and in various contexts of content. ${ }^{62}$ This lengthy text is then followed by Seifrit's epic of Alexander the Great, and here too we can see Talner's colophon and date. There is hardly any ornamentation in this codex of 260 paper leaves, with the exception of a few, simple Lombard letters drawn with red ink.

Of course it should come as no surprise that the majority of the copies of the Austrian Chronicles of 95 Seigneurs were made in Habsburg lands, since the text had put them on the top of the heraldic tree, as they aimed for political success. There are also quite a few codices that have some other text bound next to the Chronicles: nearly without exception, the chosen texts had a historical note to them, such as the war with Burgundy, the Saxon World chronicles, the Carinthian chronicle by Jakob Unrest, The chronicles of the Counts of Celje, the Hungarian chronicles by Heinrich von Mügeln, the Golden bull, the genealogy of the Habsburgs, as well as Visions of the year 1401, a book on chess, songs, etc.

Only two of these codices have Seifrit's epic of Alexander bound with the Austrian Chronicles; along with this manuscript from Kozjak, there is also the manuscript now

60 Seemüller, p. II-IV (Nr. 1), p. 216-219 (\$ 425-430); ills. fol. 176r-178v, p. 224-230.

61 The painted crests are works of varying quality; those, belonging to known aristocratic families, are painted in reliable forms; for the houses born of fantasy, crests were most often given to Abraham's (1), Nonas' (19), Mangais' (25), Saptan's (37), Retan's (43), Manton's (44), Rolan(d)'s (50), Janatan's (58), Sanatan's (61) and St. Aman's (66) houses; with the last one the Christian period begins. See Golob, 2005, p. 82.

62 Whether there was a coat-of-arms wall on the castle of the Counts of Celje is a particular question that should be solved in the context of political manifestation and self-promotion; we often forget that the chapel in Turjak was painted with a spectacular parade of knights (the Three Magi/Kings are merely an excuse for this dramatic performance), with 42 crests on the vaulted ceiling. 
kept in Vienna, ÖNB, Cod. ser. n. $4212 .{ }^{63}$ Scholarly literature sets this manuscript in the first half of the $15^{\text {th }}$ century (Menhardt, 3,1516 ), meaning it should be a few years older than Talner's copy, if the date is correct. Yet both manuscripts share some similarities: if we speak of the format, the organisation of the writing space, the number of lines etc., we can say that there are virtually no differences in their appearance. Both used a fairly low-quality paper, ${ }^{64}$ and both were copied - at least by comparing certain word formulations - after the same archetype. The initials S(eneca) at the beginning of the Austrian Chronicles (Illustration 3c), and G(ot vater) at the beginning of the epic of Alexander are undoubtedly prettier in the manuscript from Vienna.

Each manuscript is certainly the work of a different scribe, and thus the only question that remains is how Herman Talner entered into these circumstances. This man from Trebnje had finished his copy of the Austrian Chronicles on September $29^{\text {th }}, 1456$, and completed Seifrit's epic a few weeks later. The castle in Trebnje was in the possession of the Counts of Celje at the time (while the nearby Kozjak castle was not), and yet it would not seem too exaggerated to assume that news of these texts came to Ludvik of Kozjak from Celje. We have no knowledge of where Herman Talner had done his work, of where his working table stood; certainly it was not in Trebnje, his hometown, for in that case he would not have signed himself as "of Trebnje," "von treffen." Had he gone to Celje? Why not, after all it would be hard to imagine that these texts would not have been present at the court there. Of course, Lord Ludvik of Kozjak might have sent him to Vienna, and he might have copied other interesting works of science and literature in either location.

That he had not been working in his usual environment is also indicated by the materials he used: the paper is of varying quality and has several watermarks. ${ }^{65}$ It also indicates that Talner had insufficient paper in his own stocks and would have bought more in a foreign place, and we can also see changes in the tonalities of ink. None of this, however, hampered his work, as his swift copying tempo and the stable kinetics of the hand, his ductus, is virtually unchanged, which is the mark of a skilled, professional copyist. The colophon is written with a steady hand, without any mistakes (either

63 This manuscript was not known to Seemüller, as it was a part of Count Alexander Dietrichstein's private collection and was sold at an auction in 1934.

64 The paper in the manuscript intended for the Lord of Kozjak is, here and there, of such low quality that the ink bled through the sheet of paper; therefore it is at some instances very hard to read. The manuscript in Vienna is currently unavailable due to reasons of conservation (the paper is very sensitive).

65 In the Joseph Regenstein Library in Chicago a slim-light procedure for watermarks in the papers was not permitted (which would have allowed for a precise identification), so I can only claim to have determined the following watermarks: a bull's head, scissors (I believe this is the mark of the papermill in Wiener Neustadt from 1455), and a three-peaked mountain with a cross. For examples according to Piccard's catalogue, see Golob, 2005, footnote 23. 
when writing year-dates or nomina sacra); moreover, with his smooth formulation of the necessary information, he had merely added the final proof that ars scribendi was truly his forte. The hand with the pen.

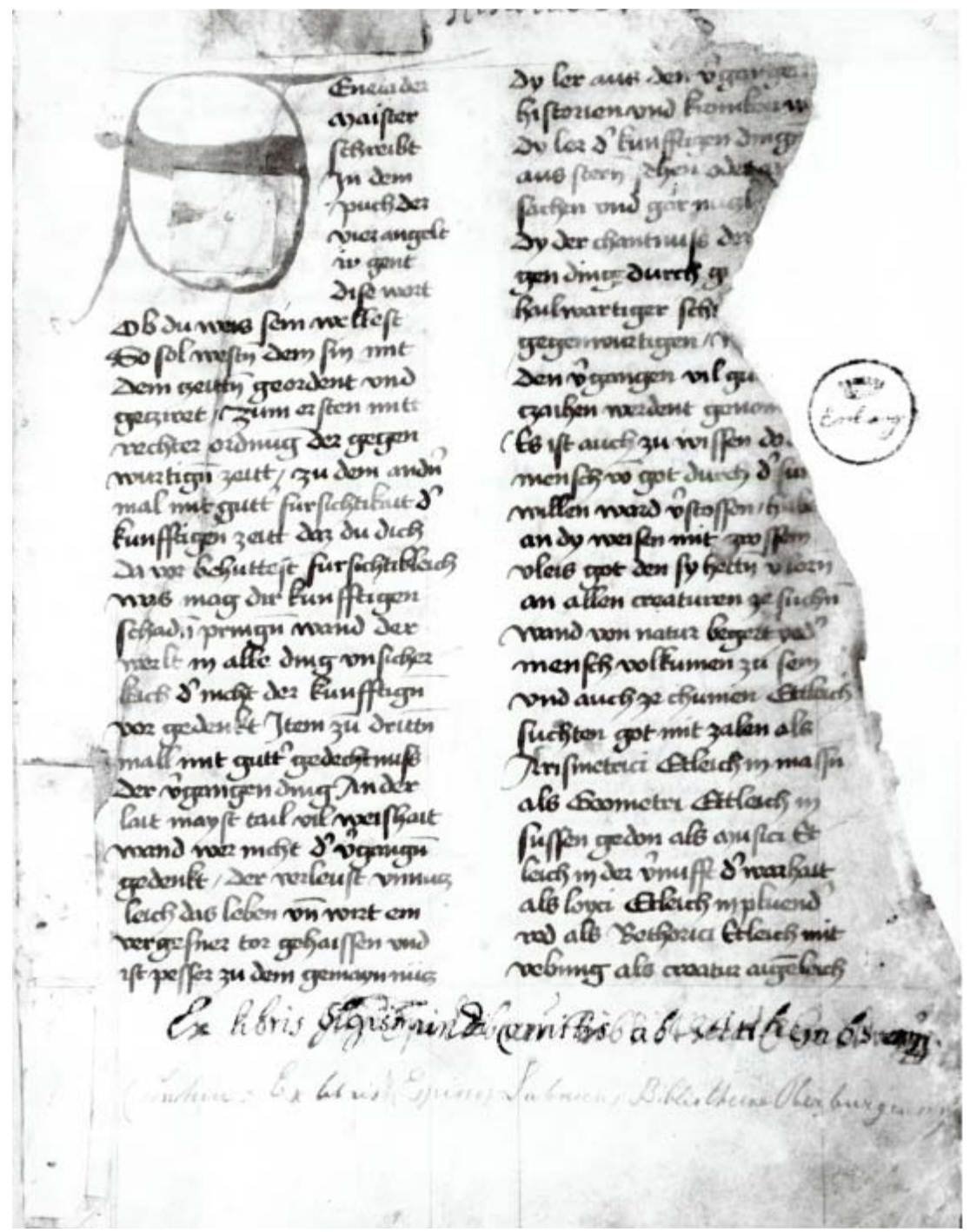

Illustration 3c: Chicago, Joseph Regenstein Library, Ms 978, fol. 1r, opening of the Austrian Chronicles of 95 Seigneurs and the two exlibrisis: from Archbishopric's Library in Gornji Grad - Ex libris Ill(ustrissi)mi Epi(scopi) Labacen(sis) Bibliotheca Oberburgensia (mid-16 ${ }^{\text {th }}$ century) and from library of Sigismund Count Attems -

Ex libris Sigismundi Comitis ab Attimensis (1736 or earlier). 
So, what is it that connects Martin of Loka, Matjaž of Kapela and Herman Talner of Trebnje? Firstly, the marginal discovery that all three of them had copied Seifrit's epic of Alexander the Great at least once (apparently it was a bestseller in these lands). From a palaeographical point of view one can say that they performed their work well, easily switching between litterae bastardae, current script, textura, Lombard letters, various types of cadels, ornamental letters, using standard abbreviations, nomina sacra, etc. They were true polygraphs. All three of them also displayed excellent knowledge of diverse languages and their plurilinguism mirrors the free intake of information: neither Latin nor German was a puzzle to anyone, and Matjaž of Kapela surprises us with several sentences in Provençal, while Martin of Loka uses some choice Slovene words. And all three of them were connected to the aristocratic environment in one way or another.

We cannot really know how many books they copied, but if they lived off of this work, they would have likely finished eight to ten books each year, accumulating many titles in the span of each man's working life. And how much knowledge they contained!

Translated by Jernej Hočevar

\section{Bibliography}

\section{Sources}

Antonius de Azaro Parmensis et al., Variae, Ljubljana, Nadškofijski arhiv, Ms. 13.

Bertholdus Frisigiensis, Summa confessorum, variae, Wien, ÖNB, Cod. 2821.

Biblia sacra, Ljubljana, NŠA, Ms. 14.

Gregorius Magnus, Libri moralium in Iob, libri XI - XVI, Ljubljana, NUK, Ms 8 / II.

Herczog Wilhalms gepetpüchlein etc., Ljubljana, NUK, Ms 140.

Leopold von Wien (?), Österreichische Chronick von 95 Herrschaften, Chicago, Joseph Regenstein Library, Ms 978.

Leopold von Wien, Österreichische Chronick von 95 Herrschaften, Wien, ÖNB, Cod.

Ser. n. 4212.

Nicolaus a Lyra, Postilla super libro psalmorum, Ljubljana, NŠA, Ms. 12.

Raimundus de Vineis (de Capua), Legenda beatae Catherine de Senis etc., Ljubljana, Narodna in univerzitetna knjižnica, Ms 12.

Seifrit, Alexanderepos, Wien, ÖNB, Cod. Ser. n. 14474. 
Seifrit, Alexanderepos, Chicago, Joseph Regenstein Library, Ms 978a.

Terentius (Publius Afer), Andria etc., Wien, Österreichische Nationalbibliothek, Cod. 3210. V.a. (Syferidus), Variae, Ljubljana, NUK, Ms 40.

Österreichische Chronik von den 95 Herrschaften (Monumenta Germaniae Historica, Deutsche Chroniken VI, ed. Seemüller, J.), Hannover, Leipzig 1909.

Raimondo da Capua, Legenda maior sive Legenda admirabilis virginis Catherine de Senis. Edizione critica a cura di Silvia Nocentini, Firenze 2013.

Spiegel der Ehren des hochstloblichsten Kayser- und Koeniglichen Erzhauses Oesterreich oder Ausfuehrliche Geschicht Schrift ...mit Kays. Rudolphi I. Geburt Jahr 1212 anfahnend und mit Kays. Maximiliani I. Todes Jahr 1519 sich endend. Erstlich vor mehr als C Jahren verfasset durch den Wohlgebornen Herrn Johann Jacob Fugger... Nuernberg MDCLXVIII.

\section{Literature}

Battaglia Ricci, L., Edizioni d'autore, copie di lavoro, interventi di autoesegesi: testimonianze trecentesche, in: "Di mano propria". Gli autografi dei letterati italiani, Roma 2009, p. 123-158.

Brunetti, G., Gli autografi nella letteratura italiana delle Origini, in: "Di mano propria". Gli autografi dei letterati italiani, Roma 2009, p. 61-92.

Brunetti, G., Les «Autographes des écrivains italiens». Serie: Dès origines jusqu'au XIV ${ }^{\mathrm{e}}$ siècle, in: Medieval Autograph Manuscripts. Proceedings of the XVII ${ }^{\text {th }}$ Colloquium of the Comité International de Paléographie Latine (ed. Golob, N.), Bibliologia vol. 36, Turnhout 2013, p. 329-338.

Cahn, W., La Bible romane. Chefs-d’oevre de l'enluminure, Fribourg, Paris 1982.

de Luca, F., Benvenuto Cellini, in: Vasari, gli Uffizi e il Duca (ed. Conforti, C.), cat. XV.11, p. 378-379.

Derolez, A., Pourqui les copistes signaient-ils leurs manuscrits? in: Scribi e colofoni. Le sottoscrizioni di copisti dalle origini all'avvento della stampa (eds. Condello, E., de Gregorio, G.), Spoleto 1993, p. 37-69.

Freeman Sandler, L., 'Written with the Finger of God'. Fourteenth-century images of scribal practice in the Liechtenthal Psalter, in: Teaching Writing, Learning to Write: Proceedings of the XVI $I^{\text {th }}$ Colloquium of the Comité International de Paléographie Latine, London 2010, p. 275-292.

Frontisi, C., Vasariana. Un autoportret inséré, in: Revue de l’art 80, 1988, p. 30-36.

Garand, M.-C., Le scriptorium de Guibert de Nogent, in: Scriptorium XXXI, 1977, p. 3-29. 
Gereke, P., Seifrits Alexander. Aus der Straßburger Handschrift (Deutsche Texte des Mittelalters 36), Berlin 1932.

Golob, N., A few comments on Glagolic colophons ( $14^{\text {th }}$ and $15^{\text {th }}$ centuries), in: Scribi e colofoni. Le sottoscrizioni di copisti dalle origini all'avvento della stampa (ed. Condello, E., de Gregorio, G.), Spoleto 1993, p. 450-461.

Golob, N., Srednjeveški kodeksi iz Stične. XII. stoletje, Ljubljana 1994.

Golob, N., Rokopis za gospoda Ludvika s Kozjaka: Avstrijska kronika o 95 gospostvih in pesnitev o Aleksandru, in: Ad fontes: Otorepčev zbornik (ed. Mihelič, D.), Ljubljana, p. 77-95.

Golob, N., Anmerkungen zu den illuminierten mittelalterlichen Handschriften der Zentralbibliothek der Wiener Franziskanerprovinz in Graz, in: Lackner, F.: Katalog der mittelalterlichen Handschriften bis zum Ende des 16. Jahrhunderts in der Zentralbibliothek der Wiener Franziskanerprovinz in Graz. Unter verantwortlicher Mitarbeit von Nataša Golob, Alois Haidinger, Maria Stieglecker, Wien 2006, p. 23-48.

Golob, N., Manuscripta. Knjižno slikarstvo $v$ srednjeveških rokopisih iz Narodne in univerzitetne knjižnice v Ljubljani, Ljubljana 2010 a.

Golob, N., Manuscripta. Pisatelji, prepisovalci, bralci / Authors, scribes, readers, Ljubljana 2010 b.

Golob, N., Knjižnica viteza, knjižnica plemiča, in: Vitez, dama in zmaj. Dediščina srednjeveških bojevnikov na Slovenskem 1: Razprave (ed. Lazar, T. et al.), Ljubljana 2011, p. 191-202.

Guichard, Ch., Fragonard et les jeux de la signature aux XVIII siècle, in: Revue de l'art 177, 2012-2013, p. 47-55.

Hamon, É., Répertoires d'artistes et humanités numériques, in: Revue de l’art 183, 2014 -1, p. 59-63.

Hoffmann von Fallersleben, H., Verzeichniss der altdeutschen Handschriften der $k$. $k$. Hofbibliothek zu Wien, Leipzig 1841, p. 337 (Nr. CCCXXXVI). [BSB online].

Kaeppeli, T., Scriptores Ordinis Praedicatorum Medii Aevi, Bd. I: A-F, Rom 1970, p. 239 (Nr. 665).

Katalog der deutschsprachigen illustrierten Handschriftendes Mittelalters, begonnen von Hella Frühmorgen-Voss, fortgeführt von Norbert H. Ott zusammen mit Ulrike Bodemann, Bd. 3, 4, München 2001.

Keil, G., Martin von Bischoflack, in: ${ }^{2}$ VL 6 (1987), col. 150f. + ${ }^{2}$ VL 11 (2004), p. XV.

Klotz, H., Formen der Anonymität und des Individualismus in der Kunst des Mittelalters und der Renaissance, in: Essays in Honour of Sumner McKnight Crosby, Gesta, 15/1976, p. 303-312. 
Kos, M. - Stele, F., Srednjeveški rokopisi v Sloveniji / Codices aetatis mediae manu scripti qui in Slovenia reperiuntur, Ljubljana 1931.

Krämer, S., Scriptores codicum medii aevi. Datenbank von Schreibern mittelalterlicher Handschriften. CD-ROM mit Begleitheft (Ein Katalog von Schreibern mittelalterlicher Handschriften aus der Zeit um 500 bis ins 16. Jahrhundert), Augsburg 2003.

Krämer, S., Scriptores possessoresque codicum medii aevi. Datenbank von Schreibern und Besitzern mittelalterlicher Handschriften, Augsburg 2006.

Kurmann, P., Mobilité des artistes ou mobilité des modèles? A propos de l'atelier des sculpteurs rémois au XIII ${ }^{\mathrm{e}}$ siècle, in: Revue de l'art 120, 1998-2, p. 23-34.

Lackner, F., Zum Kauf der Handschriften der Bibliothek des Deutschen Ordens in Wien durch die Hofbibliothek im Jahre 1861, in: Codices manuscripti 25, 1998, p. 17-33.

Lehmann-Brockhaus, O., Lateinische Schriftquellen zur Kunst in England, Wales und Schottland vom Jahre 901 bis zum Jahre 1307, 3. Band, München 1956.

Long, M., L'influenza dell'epistolografia per l'affermazione dell'autografia d'autore (sec. XI-XIII), in: Medieval Autograph Manuscripts. Proceedings of the XVII ${ }^{\text {th }}$ Colloquium of the Comité International de Paléographie Latine (ed. Golob, N.), Bibliologia, vol. 36, Turnhout 2013, p. 441-446.

Medieval Autograph Manuscripts. Proceedings of the XVIt ${ }^{\text {th }}$ Colloquium of the Comité International de Paléographie Latine (ed. Golob, N.), Bibliologia, vol. 36, Brepols 2013.

Menhardt, H., Verzeichnis der altdeutschen literarischen Handschriften der Österreichischen Nationalbibliothek, Bd. 1-3 (Veröffentlichungen des Instituts für deutsche Sprache und Literatur 13), Berlin 1960-1961. [online]

Müllenhoff, K., Scherer, W. (ed.), Denkmäler deutscher Poesie und Prosa aus dem VIII.-XII. Jahrhundert, Bd. 1: Texte, Bd. 2: Anmerkungen, 3. Auflage Berlin 1892 (Nachdruck Berlin, Zürich 1964).

Otorepec, B., K zgodovini gradu Brdo pri Kranju, in: Kronika 30, n. 1, 1982, p. 3-5.

Ott, N. H., Rechtspraxis und Heilsgeschichte. Zu Überlieferung, Ikonographie und Gebrauchssituation des deutschen,Belial' (MTU 80), München 1983, p. 177f.

Pawis R., Seifrit, in: Verfasserlexikon $8(1992)^{2}$, col. 1050-1055 + Verfasserlexikon 11 $(2004)^{2}$, col. 1419.

Petrucci, A., Il libro manoscritto, in: Letteratura italiana (ed. Asor Rosa, A.), II. Produzione e consumo, Torino 1983, p. 497-524.

Pointon, M., Sense of Self, in: Apollo, June 2014, p. 122-123.

Radics, P. pl., Slovenščina v besedi in pismu: po šolah in uradih: kulturno-zgodovinska studija, in: Letopis Matice Slovenske, Ljubljana 1879, p. 11-33. 
Reynhout, L., Formules latines de colophons, A: Texte, B: Annexes, Bibliologia, vol. 25, Turnhout 2006.

Riedlsperger, L., Die deutschsprachigen mittelalterlichen Handschriften des Benediktinerstiftes Michaelbeuern, Salzburg: Spätmittelalterliche geistliche Literatur in der Nationalsprache II, in: Analecta cartusiana 106, 1983, p. 130-144.

Schmidt, G., Beobachtungen betreffend die Mobilität von Buchmalern im 14 . Jahrhundert, in: Codices manuscripti, 42/42, 2003, p. 1-25.

Schmitt, W., Ambros, in: ${ }^{2}$ Verfasserlexikon 1 (1978), col. 327.

Schuller-Juckes, M., Ulrich Schreier und seine Werkstatt: Buchmalerei und Einbandkunst in Salzburg, Wien und Bratislava im späten Mittelalter (typewritten), Wien 2009.

Simoniti, P., Humanizem na Slovenskem in slovenski humanisti do srede 16. stoletja, Ljubljana 1979.

Slana, L., Brdo pri Kranju, Ljubljana 2009.

Stanonik, J., Ostanki srednjeveškega nemškega slovstva na Kranjskem, Ljubljana 1957.

Steer, G., Klimanek, W. et al. (ed.), Die "Rechtssumme" Bruder Bertholds. Eine deutsche abecedarische Bearbeitung der "Summa Confessorum" des Johannes von Freiburg. Synoptische Edition der Fassungen B, A und C, Bd. I: Einleitung, Buchstabenbereich A-B (Texte und Textgeschichte 11), Tübingen 1987.

Steer, G., Zur deutschen Werkbezeichnung der ,Summa Confessorum-Bearbeitung Bruder Bertholds, in: Die "Rechtssumme" Bruder Bertholds. Eine deutsche abecedarische Bearbeitung der "Summa Confessorum" des Johannes von Freiburg, Untersuchungen I, hg. von Marlies Hamm und Helgard Ulmschneider (Texte und Textgeschichte 1), Tübingen 1980.

Stelè, F., Oris zgodovine umetnosti pri Slovencih: kulturnozgodovinski poskus, Ljubljana ${ }^{2}$ 1966.

Supino Martini, P., Il libro e il tempo, in: Scribi e colofoni. Le sottoscrizioni di copisti dalle origini allavvento della stampa (ed. Condello, E., de Gregorio, G.), Spoleto 1993, p. 3-33.

Tabulae codicum manu scriptorum praeter graecos et orientales in Bibliotheca Palatina Vindobonensi asservatorum, edidit Academia Caesarea Vindobonensis, Vol. II: Cod. 2001-3500, Wien 1868.

Uiblein, P., Leopold von Wien, in: Verfasserlexikon 1985, Bd. 5, ${ }^{2}$ col. 716-723 + Verfasserlexikon 2004, Bd 11, ${ }^{2}$ col. 920.

Unterkircher, F., Inventar der illuminierten Handschriften, Inkunabeln und Frühdrucke der Österreichischen Nationalbibliothek, 1: Die abendländischen 
Handschriften (Museion. Veröffentlichungen der Österr. Nationalbibliothek, N.F. 2,2,1), Wien 1957.

Unterkircher, F., Die datierten Handschriften der Österreichischen Nationalbibliothek von 1451 bis 1500, 1.: Text, 2.: Tafeln (Katalog der datierten Handschriften in lateinischer Schrift in Österreich III), Wien 1974.

Unterkircher, F., Die datierten Handschriften der Österreichischen Nationalbibliothek von 1501 bis 1600, 1.: Text, 2.: Tafeln (Katalog der datierten Handschriften in lateinischer Schrift in Österreich IV), Wien 1976.

Valvasor, J.W., Die Ehre des Herzogthums Krain, I-IV, München 1971-1974 (facsimile).

Vasari, gli Uffizi e il Duca (ed. Conforti, C.), Firenze, Galleria degli Uffizi, 14 giugno 30 ottobre 2011.

Weck, H., Die "Rechtssumme" Bruder Bertholds. Eine deutsche abecedarische Bearbeitung der "Summa Confessorum" des Johannes von Freiburg. Die handschriftliche Überlieferung (Texte und Textgeschichte 6), Tübingen 1982.

Zinner, E., Verzeichnis der astronomischen Handschriften des deutschen Kulturgebietes, München 1925 (handwritten), Wien, ÖNB Nr. 12307.

Žontar, J., Zgodovina mesta Kranja, Kranj 1982. 
Nataša Golob

\section{Roka s peresom: kolofoni Martina iz Loke, Matjaža Jurčiča iz Kapele in Hermana Talnerja iz Trebnjega}

Ključne besede: srednjeveški rokopisi, avtograf pisatelja, avtograf prepisovalca, ideograf, prosopografija, Martin iz Škofje Loke, Matjaž Jurčič iz Kapele, Herman Talner iz Trebnjega

Prispevek se uvodoma ustavlja ob izrazih, kot so ideograf, avtograf pisatelja in avtograf prepisovalca, ter pojasnjuje dileme ob nekaterih poznosrednjeveških rokopisih iz slovenskih zbirk, ki so bili pomotoma opredeljeni kot avtografi pisateljev. Osrednji del prispevka je namenjen predstavitvi treh prepisovalcev iz sredine 15.stoletja: to so Martin iz (Škofje) Loke, Matjaž Jurčič iz Kapele in Herman Talner iz Trebnjega. Vse tri lahko prepoznamo kot osebe iz slovenskih krajev, ker so k svojemu imenu dodali ime domačega kraja. Martin iz (Škofje) Loke je bil mož velikega znanja, kar je razvidno iz njegovih samostojno sestavljenih glos, pisal je v nemščini, slovenščini in latinščini v več oblikah pisav; Matjaž Jurčič iz Kapele je bil najbrž svobodni ustvarjalec, ki je prepis epske pesnitve zaključil s kolofonom v latinščini, nemščini in provansalščini; Herman Talner pa je v nekem oddaljenem kraju prepisoval obsežno politično-programsko pesnitev za gospoda Ludvika z gradu Kozjak. Vsi trije so na koncu svojih prepisov dodali kolofone, ki so dragoceni podatki o njih samih in delovnih okoliščinah. 
Nataša Golob

\section{The Hand with the Pen: Martin of Loka, Matjaž Jurčič of Kapela and Herman Talner of Trebnje and their Colophons}

Keywords: Mediaeval manuscripts, author's autograph, copyist's autograph, ideograph, prosopography, Martin of (Škofja) Loka, Matjaž Jurčič of Kapela, Herman Talner of Trebnje

Beginning with expressions such as ideographs, the author's autograph, and the copyist's autograph, this paper explains the dilemma of some Late Medieval Manuscripts in Slovenian collections that were mistakenly identified as being the author's own textual creation. The main part of this paper focuses on three mid- $15^{\text {th }}$ century copyists: Martin of Loka, Matjaž Jurčič of Kapela, and Herman Talner of Trebnje. Because each of them added the name of their hometown to their signature, all three can be recognized as hailing from Slovenian places. Martin of (Škofja) Loka was an erudite man, and this is evident from his texts he wrote in German, Slovenian and Latin, as well as from his many forms of scripts. Matjaž Jurčič of Kapela was probably a freelance artist, and the colophon to his copy of an epic poem contains an inscription in Latin, German and Provençal. Working in a remote location, the third, Herman Talner, copied a lengthy politically-oriented poem for Lord Ludvik of Castle Kozjak. At the end of their work all three added colophons which provide valuable information about these individuals and the conditions in which they worked. 